Eni Merita dan Kinaria Afriani, Perlindungan Hukum Terhadap Istri Sebagai Korban Atas Kekerasan Dalam Rumah Tangga, Halaman 110-117

\title{
PERLINDUNGAN HUKUM TERHADAP ISTRI SEBAGAI KORBAN ATAS TINDAKAN KEKERASAN DALAM RUMAH TANGGA
}

\author{
Eni Merita ${ }^{1}$ dan Kinaria Afriani \\ ${ }^{1}$ Sekolah Tinggi Ilmu Hukum Sumpah Pemuda \\ E-mail: Riakirey.82@gmail.com
}

\begin{abstract}
Incidents of domestic violence often occur, but not many people seem to talk about it. The house that should be a place of refuge, often becomes a dangerous place for wives and children. There are various factors behind it, among others, because our society still does not consider the issue of domestic violence as a social problem, but rather an individual issue, which should not be intervened by outside parties. that according to the Law of the Republic of Indonesia No. 23 of 2004 concerning the elimination of domestic violence, Article 16 paragraph (1) states that within twenty four hours from the time of knowing or receiving a report of domestic violence, the police must immediately provide temporary protection to the victim, while Article 16 paragraph (2) states that the temporary protection as referred to in paragraph (1) is given no later than seven days after the victim is received or handled.paling lama tujuh hari sejak korban doterima atau ditangani.
\end{abstract}

Keywords: legal protection; domestic violence

\begin{abstract}
Abstrak
Peristiwa kekerasan dalam rumah tangga seringkali terjadi, tapi tampaknya tidak banyak pihak yang membicarakannya. Rumah yang seharusnya menjadi tempat berlindung, seringkali justru menjadi tempat berbahaya buat istri dan anak-anak. Berbagai faktor yang melatarbelakangi antara lain, karena masyarakat kita masih belum menganggap bahwa persoalan kekerasan dalam rumah tangga sebagai persoalan sosial, melainkan persoalan individual, yang tidak boleh diintervensi pihak luar. bahwa menurut Undang - Undang Republik Indonesia No. 23 Tahun 2004 tentang penghapusan kekerasan dalam rumah tangga, di dalam Pasal 16 ayat (1) menyatakan bahwa dalam satu kali dua puluh emapt jam terhitung sejak mengetahui atau menerima laporan kekerasan dalam rumah tangga, kepolisian wajib segera memberikan perlindungan sementara pada korban, sedangkan Pasal 16 ayat (2) menyatakan bahwa perlindungan sementara sebagaimana dimaksud pada ayat (1) diberikan paling lama tujuh hari sejak korban doterima atau ditangani.
\end{abstract}

Kata Kunci : perlindungan hukum; kekerasan dalam Rumah Tangga

\section{PENDAHULUAN}

Perkembangan Sejarah perjuangan lahirnya kebijakan dalam melindungi korban kekerasan dalam rumah tangga yang dibentuk dalam undang-undang, tidak saja disadari dan didasari bahwa adanya jaminan dalam konstitusi indonesia yang secara tegas dan jelas melindungi hak-hak asasi manusia dan perlindungan terhadap tindakan diskriminasi. Kebijakan yang sudah diratifikasi oleh Negara Republik Indonesia melalui Undang-Undang nomor 7 Tahun 1984 juga memerlukan kebijakan organik. Sebagai Negara Pihak, Indonesia menindaklanjutinya 
Eni Merita dan Kinaria Afriani, Perlindungan Hukum Terhadap Istri Sebagai Korban Atas Kekerasan Dalam Rumah Tangga, Halaman 110-117

melalui Pengesahan Undang-Undang Nomor 23 Tahun 2004 tentang Penghapusan Kekerasan dalam Rumah Tangga (UU PKDRT) yang dalam pertimbangan serta pengaturannya sarat dengan muatan yang memperhatikan perspektif Hak Asasi Manusia (HAM) dan gender. Satu hal yang tampak jelas dan tegas dalam pengaturan $\mathrm{UU}$ PKDRT adalah dicantumkannya pengertian "kekerasan dalam rumah tangga" yang dalam perumusannya juga telah mempertimbangkan ketentuan-ketentuan sebagaimana dimuat dalam CEDAW beserta Rekomendasi Umum Nomor 19 Tahun 1992 tentang Kekerasan terhadap Perempuan. ${ }^{1}$

Keluarga merupakan lingkungan sosial pertama yang dikenal oleh manusia. Dalam keluarga manusia belajar untuk mulai berinteraksi dengan orang lain. Karena itulah, umumnya orang banyak menghabiskan waktunya dalam lingkungan keluarga.

Sekalipun keluarga merupakan lembaga sosial yang ideal guna menumbuh kembangkan potensi yang ada pada setiap individu, dalam kenyataannya keluarga seringkali

\footnotetext{
1 Komisi Nasional Anti Kekerasan terhadap Perempuan (Komnas Perempuan), 2013.
}

menjadi wadah bagi munculnya berbagai kasus penyimpangan atau aktivitas ilegal lain, sehingga menimbulkan kesengsaraan atau penderitaan, yang dilakukan oleh anggota keluarga satu terhadap anggota keluarga lainnya, seperti penganiayaan, pemerkosaan, pembunuhan. Situasi inilah yang lajim disebut dengan istilah Kekerasan Dalam Rumah Tangga. ${ }^{2}$

Pada umumnya, dalam struktur kekerabatan di Indonesia, kamu lakilaki ditempatkan pada posisi dominan, yakni sebagai Kepala Keluarga, sehingga bukan hal yang aneh apabila kemudian anggota keluarga lainnya menjadi sangat tergantung kepada kaum laki-laki.

Adanya sikap tradisional bahwa perempuan dianggap sebagai subordinasi laki-laki, pembakuan peran-peran stereotipe, disertai dengan sikap tradisional perempuan seperti keberuntungan sosial dan ekonomi pada suami dan keluarga serta rasa

2 Pasal 1 angka 1 Undang-Undang No. 23 Tahun 2004 tentang Peghapusan Kekerasan dalam Rumah Tangga mendefinisikan kekerasan dalam rumah tangga adalah setiap perbuatan terhadap seseorang terutama perempuan, yang berakibat timbulnya kesengsaraan atau penderitaan secara fisik, seksual, psikologis, dan/atau penelantaran rumah tangga termasuk ancaman untuk melakukan perbuatan, pemaksaan, atau perampasan kemerdekaan secara melawan hukum dalam lingkup rumah tangga. 
Eni Merita dan Kinaria Afriani, Perlindungan Hukum Terhadap Istri Sebagai Korban Atas Kekerasan Dalam Rumah Tangga, Halaman 110-117

takut dan keengganan perempuan korban kekerasan untuk mendapatkan keadilan, merupakan sebab-sebab utama di antara sekian sebab lainnya yang menyebabkan bahwa tindak kekerasan dalam rumah tangga tidak terungkap atau tidak di atasi. ${ }^{3}$

Kejadian suami yang membakar istrinya pernah terjadi, suami yang memukul dan mengakibatkan luka memar pada istri tidak terhitung lagi jumlahnya, orang tua yang memukul anaknya hingga meninggal pernah terjadi. Penganiayaan yang berakibat timbulnya kesengsaraan atau penderitaan secara fisik, seksual, ekonomi, psikologi termasuk ancaman pemaksaan dan pemerasan dalam lingkup rumah tangga banyak terjadi, tidak hanya dalam lingkup rumah tangga, pada lingkup tempat kerja, masyarakat atau negara juga dapat terjadi tindak kekerasan dan kecenderungan korban adalah wanita atau anak-anak, apakah korban tersebut adalah istri atau pembantu rumah tangga atau orang lain yang lemah.

Seseorang yang melakukan kekerasan adalah orang yang tingkat

3 Achie Sudiarti Luhulima dan Kunthi Tridewiyanti, Pola Tingkah Laku Sosial Budaya dan Kekerasan Terhadap Perempuan, (Suatu Tinjauan Hukum) (Jakarta: Universitas Indonesia, 1999). pemahaman agamanya kurang baik dan memiliki tingkat pemahaman hukum yang kurang sehingga melakukan pelanggaran. ${ }^{4}$ Pemahaman agama yang kurang yang tercermin dalam tingkah laku yang buruk dapat memicu tindakan kekerasan atau penyikasaan.

Kesulitan ini menimbulkan pertanyaan mengenai apa yang akan dilakukan untuk meningkatkan rasa tanggung jawab anggota masyarakat, sehingga mereka tergerak untuk berperan serta menanggulangi kekerasan dalam keluarga dan bersedia membela hak-hak pihak korban dimana saja serta kapan saja. Dalam hal ini pandangan setiap orang yang dapat menjadi motivasi kegiatannya dalam masyarakat tersebut harus diperhitungkan. Termasuk disini pihak yang menimbulkan korban maupun pihak yang menjadi korban, serta aparat pemerintah. ${ }^{5}$

Persoalan KDRT pada istri, anakanak atau pembantu sering terjadi dan belum selesai, selalu terjadi kasus. Mengapa hal ini terus terjadi?

4 Dikdik M. Aried Mansur dan Elisatris Gultom, Urgensi Perlindungan Korban Kejahatan Antara Norma dan Realita, (Bandung, 2006).

5 Arif Gosita, Masalah Korban Kejahatan (Kumpulan Karangan) (Jakarta: Akademika Pressindo, 1993). 
Eni Merita dan Kinaria Afriani, Perlindungan Hukum Terhadap Istri Sebagai Korban Atas Kekerasan Dalam Rumah Tangga, Halaman 110-117

Kekerasan atau Penganiayaan terus terjadi dapat saja disebabkan oleh :

1) Kesadaran yang kurang terhadap persoalan KDRT. Kekerasan dalam hal ini adalah persoalan sosial, bukan individu hingga perlu penyelesaian yang melibatkan pihak ketiga dengan melapor apabila terjadi penganiayaan.

2) Korban KDRT tidak berani mempersoalkan penderitaannya kepada pihak lain seperti Lembaga yang mendampingi/peduli pada korban seperti : LBH Apik, Mitra, Perempuan, dan lain-lain. Korban KDRT menganggap hal yang biasa dalam rumah tangga mereka hingga tidak perlu orang lain tahu. Korban lebih memilih diam atau berdamai dengan pelaku dengan alasan-alasan tertentu, kecenderungan korban menginginkan keluarganya utuh.

3) Lemahnya sanksi dalam kekerasan atau penganiayaan di rumah tangga. UU Khusus (UU Anti Kekerasan/Anti KDRT) belum berbicara secara tajam mengenai sanksi kurungan, sedangkan hukuman sering terlalu ringan atau tidak maksimal, serta seluruh kerugian sering ditanggung korban dan tidak ada perlindungan bagi korban dan saksi kejadian dan yang lebih fatal adalah menganggap KDRT bukan pelanggaran hukum. Padahal KDRT adalah kejahatan yang dapat dijaring oleh UndangUndang untuk dihukum.

Tindak kekerasan terhadap perempuan bisa dikatakan sebagai salah satu bentuk kejahatan yang paling banyak tidak dilaporkan oleh korban dan atau keluarganya kepada yang berwenang menanganinya. Ini antara lain disebabkan rasa malu, juga tak percaya diri, karena korban merasa peradilan pidana belum tentu dapat membuat pelakunya dipidana korban juga bisa khawatir kasus ini akan justru mencemarkan namanya disamping ketakutan akan balasan si Pelaku.

Tindak kekerasan terhadap perempuan bisa dikatakan sebagai salah satu bentuk kejahatan yang paling banyak tidak dilaporkan oleh korban dan atau keluarganya kepada yang berwenang menanganinya. Ini antara lain disebabkan rasa malu, juga tak percaya diri, karena korban merasa peradilan pidana belum tentu dapat membuat pelakunya dipidana korban juga bisa khawatir kasus ini akan justru 
Eni Merita dan Kinaria Afriani, Perlindungan Hukum Terhadap Istri Sebagai Korban Atas Kekerasan Dalam Rumah Tangga, Halaman 110-117

mencemarkan namanya disamping ketakutan akan balasan si Pelaku.

Dalam penulisan ini mengangkat permasalahan bagaimanakah perlindungan hukum terhadap istri sebagai korban KDRT menurut Undang-Undang Nomor 23 Tahun 2004.

\section{PEMBAHASAN}

Kekerasan terhadap perempuan yang dibayangkan hanya terjadi di medan perang atau sebatas ekspresi kemenangan dan shockb therapy terhadap musuh yang telah berhasil dikalakan dengan cara memperkosa dan membunuh perempuan serta anak anak, tetapi kekerasan terhadap kaum perempuan sesungguhnya paling sering terjadi di rumah tangga, dalam sebuah keluraga yang dari luar terlihat tak bermasalah, penderitaan dan penganiayaan terjadi dari hari ke hari.

Masalah utama yang berkaitan dengan perlindungan hokum terhadap perempuan korban kekerasan khususnya korban penganiayaan suami terhadap isteri, berpusat pada adanya hukum yang secara khusus memberi perlindungan bahkan istilah kekerasan pun tidak dikenal dalam hukum
Indonesia, meski fakta itu muncul semakin marak di wilayah Indonesia.

Dalam KUHP sebagai kasus yang tergolong kekerasan terhadap perempuan memang dapat dijaring oleh pasal-pasal kejahatan atau pidana dengan korban perempuan, seperti kesusilaan, pemerkosaan, penganiayaan dan lain-lain, yang dirumuskan dalam pengertian sempit dengan pemberatan hukum yaitu kalau perbuatan tersebut dilakukan dalam keluarga seperti terhadap ibu, istri, dan anak.

Istilah kekerasan yang dipakai Kantor Menteri Peranan Wanita tidak semata - mata hanya kekerasan fisik dalam arti menyakiti dalam derap ketiga rancangan aksi nasional penghapusan kekerasan terhadap perempuan tahun 2001-2004, kekerasan terhadap perempuan adalah :

Setiap tindakan yang melanggar, menghambat, meniadakan kenikmatan, dan pengabadian hak azasi manusia atas dasar gender. Tindakan tersebut dapat mengakibatkan kerugian terhadap perempuan secara fisik, seksual dan psikis, termasuk ancaman perbuatan tersebut, paksaan atau perampasan kemerdekaan secara sewenang-wenang baik dalam 
Eni Merita dan Kinaria Afriani, Perlindungan Hukum Terhadap Istri Sebagai Korban Atas Kekerasan Dalam Rumah Tangga, Halaman 110-117

kehidupan berkeluarga, bermasyarakat dan bernergara. ${ }^{6}$

Kekerasan fisik adalah "setiap peraturan yang menyebabkan rasa sakit cedera, luka, cacat patah tulang seseorang, dan atau menyebabkan, kematian" Persoalan kekerasan terhadap perempuan ditegaskan oleh Muladi ketika menjabat Menteri Kehakiman:

Bahwa tidak bisa lagi dipandang sebagai masalah individual, tetapi sudah menjadi masalah nasional dan internasional, karenanya menjadi masalah global sebab dalam persoalan ini terkait isu global mengenai hak azasi manusia (HAM) yang diartikan sebagi hak-hak yang melekat (inheren) secara alamiah sejak manusia dilahirkan. $^{7}$

Pelaku penganiayaan terhadap perempuan (dalam berbagai bentuk kekerasan) ternyata tidak terbatas pada usia, tingkat pendidikan agama, status sosial, ekonomi, suku, kondisi fisikopatologi maupaun hal-hal lain, mereka dapat berasal dari berbagai latar belakang seakan-akan mewakili semua laki-laki pada umumnya.

\footnotetext{
6 Kompas, "Jangan Melupakan Akar Kekerasan,” Rabu 18 uni 2010: 28.

${ }^{7}$ Kompas.
}

Khusus untuk penganiayaan yang terjadi dalam lingkup rumah tangga atau hubungan intim yang tampaknya menunjukkan cukup banyak kesamaan adalah latar belakang kehidupan pelaku, dan kepribadian yang berkaitan dengan tingkah laku agresif. Cukup banyak pelaku berasal dari keluarga dalam hidup sehari-harinya kekerasan merupakn hal yang biasa, melihat ibunya sering menjadi sasaran kekerasan dan mereka sendiri sebagai anak mengalami perilaku kekerasan tersebut. Mereka belajar bahwa kekerasam sebagai bentuk pengkambing hitaman ataupun sekedar sebagai tumpahan frustasi merupakan bentuk penyelesaian konflik yang biasa dapat diterima.

Diskriminasi terhadap kaum wanita menyimpangi prinsip-prinsip persamaan hak dan penghormatan terhadap martabat manusia, yang merupakan suatu kendala bagi partisipasi kaum wanita, atas dasar syarat - syarat yang sama dengan kaum pria dalam kehidupan politik, sosial, ekonomi dan kehidupan budaya dinegaranya, mengganggu pembangunan kesejahteraan masyarakat dan keluarga serta lebih mempersulit pengembangan potensi 
Eni Merita dan Kinaria Afriani, Perlindungan Hukum Terhadap Istri Sebagai Korban Atas Kekerasan Dalam Rumah Tangga, Halaman 110-117

wanita sepenuhnya dalam pelaksnaan dinas dinegaranya dan pembangunan kemanusiaan.

Disimpulkan bahwa menurut Undang - Undang Republik Indonesia No. 23 Tahun 2004 tentang penghapusan kekerasan dalam rumah tangga, di dalam Pasal 16 ayat (1) menyatakan bahwa dalam satu kali dua puluh emapt jam terhitung sejak mengetahui atau menerima laporan kekerasan dalam rumah tangga, kepolisian wajib segera memberikan perlindungan sementara pada korban, sedangkan Pasal 16 ayat menyatakan bahwa perlindungan sementara sebagaimana dimaksud pada ayat (1) diberikan paling lama tujuh hari sejak korban doterima atau ditangani.

Pada kenyataannya kasus kekerasan dalam rumah tangga (KDRT) banyak terjadi. Adapun sistem hukum di Indonesia belum mejamin perlindungan terhadap korban kekerasan yang terjadi dalam lingkup rumah tangga. Yang dimaksud dengan kekerasan dalam rumah tangga adalah :

"Setiap perbuatan terhadap
seseorang terutama perempuan,
yang berakibat timbulnya
kesengsaraan atau penderitaan

secara fisik, psikologis dan/atau penelantaran rumah tangga termasuk ancaman untuk melakukan perbuatan, pemaksaan atau perampasan kemerdekaan secara melawan hukum dalam lingkup rumah tangga" (Pasal 1 ayat (1) Undang-Undang Nomor 23 Tahun 2004).

Dalam Pasal 2 Undang-Undang Nomor 23 Tahun 2004 disebutkan bahwa lingkup rumah tangga dalam undang-undang ini meliputi :

1. Lingkup rumah tangga dalam undang-undang ini meliputi :

a. Suami, istri, dan anak;

b. Orang-orang yang mempunyai hubungan keluarga dengan orang sebagaimana dimaksud pada huruf a karena hubungan darah, perkawinan, persusuan, pengasuhan, dan perwalian, yang menetap dalam rumah tangga; dan

c. Orang yang bekerja membantu rumah tangga dan menetap dalam rumah tangga tersebut.

2. Orang yang bekerja sebagaimana dimaksud huruf $\mathrm{c}$ dipandang sebagai anggota keluarga dalam jangka waktu 
Eni Merita dan Kinaria Afriani, Perlindungan Hukum Terhadap Istri Sebagai Korban Atas Kekerasan Dalam Rumah Tangga, Halaman 110-117

selama berada dalam rumah tangga yang bersangkutan.

Adapun asas dan tujuan disusunnya undang-undang ini tercantum dalam Pasal 3 dan Pasal 4 Undang-Undang Nomor 23 Tahun 2004 sebagai berikut: Penghapusan kekerasan dalam rumah tangga dilaksanakan berdasarkan asas :

a. Penghormatan hak asasi manusia;

b. Keadilan dan kesetaraan gender;

c. Nondiskriminasi; dan

d. Perlindungan korban. ${ }^{8}$

\section{KESIMPULAN}

Perlindungan Hukum seorang istri yang dianiaya oleh suaminya sendiri, menurut Undang-Undang Republik Indonesia No. 23 Tahun 2004 tentang penghapusan kekerasan dalam rumah tangga, di dalam pasal 16 ayat (1) dinyatakan bahwa dalam satu kali dua puluh empat jam terhitung sejak mengetahui atau menerima laporan kekerasan dalam rumah tangga, kepolisian wajib memberikan perlindungan sementara pada korban, sedangkan pasal 16 ayat

8 Evi Purnamawati, "Sosialisasi UndangUndang No. 23 Tahun 2004 tentang Penghapusan Kekerasan dalam Rumah Tangga (KDRT)" https://evilaws.blogspot.com/2013/10/sosialisa si-undang-undang-ri-nomor-23.html, 2021. menyatakan bahwa perlindungan sementara pada ayat (1) diberikan paling lama tujuh hari sejak korban diterima dan ditangani.

\section{DAFTAR PUSTAKA}

Achie Sudiarti Luhulima dan Kunthi Tridewiyanti, Pola Tingkah Laku Sosial Budaya dan Kekerasan Terhadap Perempuan, (Suatu Tinjauan Hukum), Jakarta: Universitas Indonesia, 1999.

Arif Gosita, Masalah Korban Kejahatan (Kumpulan Karangan), Jakarta: Akademika Pressindo, 1993.

Dikdik M. Aried Mansur dan Elisatris Gultom, Urgensi Perlindungan Korban Kejahatan Antara Norma dan Realita, Bandung, 2006.

Evi Purnamawati, "Sosialisasi Undang-Undang No. 23 Tahun 2004 tentang Penghapusan Kekerasan dalam Rumah Tangga (KDRT)"

https://evilaws.blogspot.com/201 3/10/sosialisasi-undang-undangri-nomor-23.html, 2021.

Komisi Nasional Anti Kekerasan terhadap Perempuan (Komnas Perempuan), 2013.

Kompas, "Jangan Melupakan Akar Kekerasan," Rabu 18 uni 2010: 28.

Undang-Undang Nomor 23 Tahun 2004 tentang Peghapusan Kekerasan dalam Rumah Tangga. 